\section{QUAL É O MODELO BRASILEIRO DE MODERNIDADE?}

"A história pode ser vista como um fluxo ininterrupto, onde passado e futuro se entrelaçam num presente, mais ou menos revelador dos processos responsáveis pelas grandes mudanças. Estas nem sempre são percebidas, porque têm suas origens em movimentos de fundo, acelerações até então desconhecidas e com a entrada em cena de novos atores".

\section{Prof. Milton Santos}

Com este parágrafo, o geógrafo e professor emérito da USP Milton Santos, recentemente falecido, iniciava seu artigo "Por um Modelo Brasileiro de Modernidade", publicado no "Correio Braziliense" em 2000.

Estas palavras emprestadas podem, com pertinência, servir de preâmbulo a um dos temas da pauta atual da C\&T do País, em particular as redes de pesquisa científica. Neste contexto, uma indagação surge: será este o novo paradigma brasileiro de desenvolvimento científico? Será esta a vertente principal da política científica nacional, em vigor, com as prioridades definidas e debatidas com a comunidade científica e a sociedade, tendo finalmente financiamentos meritocraticamente contínuos, assegurando a execução dos projetos e a renovação dos recursos humanos qualificados, profissionalmente valorizados?

Dentro destas redes incluem-se PRONEX, Instituto do Milênio, Projetos Temáticos de algumas FAPs, Fundos Setoriais, RECOPE, etc., cujo objetivo principal é congregar pesquisadores de diversos departamentos, universidades, institutos de pesquisa de diferentes estados, em torno de um mesmo projeto científico multi- e transdisciplinar. O exemplo mais recente de redes de pesquisa científica é o Projeto Genoma da FAPESP, que tem associado o desenvolvimento científico no campo da genômica com as áreas biomédica e agrícola, principalmente na formação de recursos humanos de alto nível. Portanto, a idéia de grupos de pesquisa isolados contribuindo para um projeto comum, não necessariamente sendo o tema um trabalho específico, parece ser positivo para o desenvolvimento científico. A sua modalidade induzida em áreas previamente definidas pelo governo, como os "Institutos do Milênio" para estudos do semi-árido, oceanografia e da Amazônia, também parece ser positiva, pois a ação de grupos fortes em torno de um tema pode levar a um avanço mais rápido nesta área. Todavia, se esse tema não for bem articulado entre os grupos, levando em consideração principalmente suas potencialidades, poderão estar sendo formadas redes $a r$ tificiais de pesquisa, cujo objetivo principal é obter recursos para os projetos individuais de cada grupo. Se o pressuposto é de que os projetos em rede são oriundos de associações naturais entre os pesquisadores, está, então, na contramão do projeto original.

Os mais otimistas dizem que neste novo paradigma de financiamento, os projetos terão objetivos bem definidos, com a inclusão de grupos emergentes, recursos estáveis e periódicos, que terão papel fundamental para elevar o País a novos níveis de competência nestes campos do conhecimento, sem a alegada "pulverização" de recursos. Os mais críticos afirmam que este modelo concentra recursos para poucos grupos, que está na contramão dos ideais da sociedade brasileira, empenhada em construir uma realidade menos excludente e que inibirá os avanços de novos grupos em projetos espontâneos, tão salutar para o desenvolvimento da pesquisa, sobretudo, mas não somente, a básica. Neste embate ideológico ambos os lados têm razão. Aparentemente, existem movimentos de fundo e acelerações desconhecidas da comunidade (parafraseando o Prof. Milton Santos). Se por um lado pode haver um salto qualitativo no desenvolvimento científico e tecnológico do País em certos campos do conhecimento, por outro aprofundar-se-á o abismo entre as regiões onde as pesquisas estão mais consolidadas, que serão os líderes naturais destes projetos e aquelas onde ainda não se consolidaram as condições favoráveis ao desenvolvimento científico, seja por ausência de uma atuação efetiva de FAP, seja pela inexistência de massa crítica qualificada. Outros pontos a se considerar dizem respeito à avaliação destas iniciativas, tais como: qual a avaliação dos resultados efetivos obtidos no âmbito do PRONEX? por que este programa foi, praticamente, abandonado, se dos 84 projetos que tiveram início em 1997 quantos continuam com o apoio do CNPq até 2002? até onde vai a influência do Banco Mundial nestes programas? por que não foram honrados os projetos aprovados pelo PADCT III (exceto aqueles pela FAPERJ)? Estas e muitas outras são questões que merecem maior debate na comunidade.
Se a formação de redes de pesquisa representar, como parece, o modelo em voga da política nacional de desenvolvimento científico, i.e. da pesquisa, para enfrentar os grandes desafios globais da defasagem tecnológica do País, hèlas ilustrada pela atual situação energética, este parece estar defasado da realidade que os cientistas enfrentam no dia a dia, representando um modelo menos distributivo e mais concentrador. Senão vejamos: de cada mil trabalhadores brasileiros, apenas um se dedica à pesquisa ou tecnologia, representando um efetivo cinco vezes menor do que a média mundial. As Universidades Públicas onde se realizam, com sucesso, mais de $80 \%$ dos projetos de pesquisas no País, particularmente aquelas do sistema federal de educação superior, encontram-se à deriva e sofrendo indubitável processo de privatização. O fundo setorial de infra-estrutura destinado a estas instituições, formado por recursos privados, apoiará apenas algumas das Universidades Federais produtivas, e ainda assim apenas no que diz respeito a sua infra-estrutura de pesquisa instalada, como se as outras atividades fins não contassem. Os docentes e funcionários das IFES estão com os salários congelados há quase sete anos, representando uma estratégia perversa de desestímulo à carreira científica e favorecendo a evasão de competência, além de desmoralização da atividade científica em termos sociais. Neste contexto, não é por acaso que não se realizam concursos públicos para a renovação dos quadros de professores, a despeito da significativa redução da força de trabalho docente ao longo destes anos, seja por envelhecimento, seja por receio da implantação de decantadas ameaçadoras alegações de perda de direitos como mudança nas regras da aposentadoria. Nenhuma iniciativa conseqüente para o aproveitamento de doutores capacitados e qualificados, inserindo-os no sistema produtivo de C\&T do País, pode ser lembrada facilmente. Ao contrário, o aviltamento do valor das bolsas concedidas pelo sistema federal (CNPq \& CAPES) e seu contínuo estrangulamento, a tal ponto que se cunharam nos gabinetes acarpetados, longe, portanto, dos laboratórios de pesquisa, termos como "descontingenciamento" do sistema, entre outros, meras iniciativas de se atenuar a evidente perversidade destas políticas. O paradoxo chega a ser extremo. No maior sistema de pósgraduação da América Latina, com mais de 30 anos de existência, não se vislumbra nenhuma política de captação dos recém-doutores formados no Brasil e no exterior. O recentemente criado PROFIX, previsto para ter início em 2002, no CNPq, acena com míseras cem oportunidades de fixação, precária, de doutores, sabendo que o contingente formado em 2000, atingiu 5000! Esta iniciativa representa a absorção de apenas $2 \%$ dos nossos recém-doutores e não pode ser considerada em nada diferente a uma medida paliativa, típica de ano pré-eleitoral. As bolsas de iniciação científica, mestrado e doutorado do sistema federal estão congeladas também há 7 anos, acompanhando os salários docentes, compondo o cenário de desestímulo à $\mathrm{C} \& \mathrm{~T}$ traçado pela política em vigor. Neste contexto, os pósgraduandos do sistema federal, parte expressiva dos futuros quadros qualificados do País, não podem dedicar-se como deviam à atividade científica, sendo obrigados, principalmente aqueles que já constituíram famílias, a desempenharem uma segunda jornada de trabalho, em horários não conflitantes com a atividade principal, geralmente noturna, também mal remunerada, mal sobrevivendo e correndo severos riscos de perda da dignidade profissional, futura. Alguns são sumariamente excluídos do sistema, abdicando da pósgraduação em função do valor irrisório das bolsas. Criaram-se assim jovens MST e DST, seja: mestres-sem-trabalho e doutores-sem-trabalho!

Nesta realidade, a entrada em cena dos novos atores representados pelas grandes redes de pesquisa, como política nacional científica, em implantação pelo MCT, precisa obrigatoriamente vir acompanhada de outras ações. Urge o aporte de recursos adicionais perenes, em quantidades adequadas às necessidades reais do sistema de $\mathrm{C} \& \mathrm{~T}$, capazes de contemplar também os pequenos projetos de pesquisa, executados por pesquisadores-juniores, pois estes serão, certamente, os seniores de amanhã. Urge, recompor, com base nos verdadeiros e reais índices inflacionários da economia brasileira, a questão salarial dos docentes e funcionários das IFES, bem como dos valores das bolsas, como fez a FAPESP ( ca. $35 \%$ superior àquelas $\mathrm{CNPq}$ ), sob pena de consumar-se o óbvio: não haverá mais procura por parte de futuros alunos para a pós-graduação, assim como aqueles titulados mais capacitados não se interessarão em prestar concursos que já não mais existem, para ingressarem numa carreira em franco extermínio, no País que certamente estará, com estas políticas, abrindo mão do seu futuro, e de um dos principais referenciais de esperança para nossa juventude!

Retornando aos valiosos ensinamentos do nosso saudoso Prof. Milton Santos, ao qual dedicamos este Editorial, lembramos que em uma de suas palestras dizia: "o mais importante da modernidade à brasileira é não enxergála como um dogma, uma obrigação ou um credo". 